IRSTI: 06.56 .31

UDK: 332.145

https://doi.org/10.46914/1562-2959-2021-1-4-140-146

\author{
K.T. KABDESOV, *1 \\ master, senior lecturer. \\ *e-mail:kabdesov.k@uib.kz \\ A.V. MALDYNOVA, ${ }^{1}$ \\ master, senior lecturer. \\ e-mail: maldynova.a@uib.kz \\ ${ }^{1}$ Kenzhegali Sagadiyev \\ University of International Business \\ Kazakhstan, Almaty
}

\title{
COMMUTING IN ALMATY AGGLOMERATION: AN ANALYSIS OF PILOT SURVEY RESULTS
}

\begin{abstract}
Commuting is a process that occurs frequently, usually in bigger cities and agglomerations. People living in the periphery tend to travel to work that is located in the center of agglomeration. The choice to commute can vary among the population, and that is explained by internal and external factors such as the economic and financial situation of people, labor market, etc. Even though a routine activity is a central concept of commuting, it takes place in different forms and ways and is impacted by various sociodemographic, economic, and spatial aspects. Hence, it is these social and economic changes in commuting tendencies, characters, and behaviors that this study aims to classify, analyze, and comprehend. Almaty is one of the most populated cities in Kazakhstan. Due to the urbanization processes and urban development, the city captures new territories and becomes an agglomeration. This leads to increased daily human mobility. People living in the periphery of the agglomeration, but working in downtown, travel to their workplace. Therefore, they conduct commuting. Studying commuting is important for the city's development. The purpose of this article is to identify the characteristics of pendulum migration based on the analysis of the results of a pilot survey conducted in the Almaty region. The methods of descriptive statistics are used for the analysis of the survey results.
\end{abstract}

Key words: commuting, urbanization, agglomeration, suburbanization, urban economy, survey, statistics.

\section{Introduction}

Due to the rapid growth of the cities, excessive population density conflicts with further productivity growth. Territorial opportunities for expanding production are limited, transport is overloaded, and living conditions are getting worse due to crowding, high cost, air pollution, and noise. As a result, the city begins to grow extensively - it captures all new territories and is transformed into an agglomeration $[3,4]$.

Urbanization can be characterized as one of the pillars of the Kazakhstan-2050 strategic plan. As commuting processes are closely connected with the urbanization rate, it is crucial to analyze commuting in order to maintain a sustainable urbanization rate. In Kazakhstan, the urbanization rate remains low compared with other countries. According to the National Bureau of Statistics of the RK, the share of the urban population in 2020 is $57 \%$ of the whole country population. There are some factors that explain the low urbanizations rate in Kazakhstan: the high living expenses in big cities such as Nur-Sultan and Almaty refrains most of the potential migrants; the increasing population in rural areas [5]. According to Seitz, Almaty is $190 \%$ more expensive compared with the average in the country, whereas Nur-Sultan is $240 \%$.

Another factor that impacts the urbanization rate is the increasing population in rural areas. The largest population growth over the past ten years occurred precisely in rural areas (villages) with a population of over 10 thousand people. According to the Law of the RK on the administrative-territorial structure, to obtain the status of a city, a settlement has to meet the following criteria: the population of the settlement should exceed 10 thousand people; $2 / 3$ of the population should be workers and their family members employed in the non-agricultural sector. As a result, there are villages where the 
population has already exceeded 20 people, but the local government and development plans are the same as with villages of two or three thousand inhabitants. Moreover, the agricultural sector cannot produce a labor demand that would satisfy the supply produced by a rapidly growing population. Therefore, higher spatial mobility, specifically commuting can be traced in these regions.

\section{Literature review}

Commuting takes a significant place in modern economic systems worldwide, as well as in a particular country. At the microeconomic level, it affects people's behavior and their income, household activities, and even individual entrepreneurs. At the macroeconomic level, it has tangible effects on national economic indicators, such as employment and unemployment rates, local labor markets, housing prices, and urban economics.

Such factors as wage, labor market, housing prices, commuting distance, etc. have an impact on the decision to commute and migrate [1, p. 466]. Therefore, commuters pay attention to the commuting costs. Some scholars believe that higher wages and lower housing prices would compensate for high commuting costs, relying on perfect market theory [6]. On a contrary, other scholars believe that commuting costs cannot be minimized due to the house and labor market imperfections, such as uncertainty, lack of information, and transportation costs [7]. Hence, it is important to pay attention to the concept of "excess commuting" introduced by Hamilton \& Röell in 1982. It basically can be defined as the supplementary travel to work characterized by the distinctions between the real average commuting and the minimum possible average commuting, followed by the spatial structure of the place of work and urban sites [8].

The reasons why people commute can differ depending on the category of people and their income. People who cannot afford to buy housing near the workplace are forced to travel to the center of the agglomeration for earning money etc. Whereas wealthy people prefer to live in the periphery in order to avoid city noise, air pollution, crime rates, etc. [9].

However, in Kazakhstan, there are no studies specifically related to commuting. This can be explained by several reasons: 1) the lack of official statistics on commuting 2) the high cost and complexity of quantitative studies of commuting 3 ) urban agglomerations still being in the process of formation.

\section{Materials and methods}

Desk research was intended to understand the patterns of commuting in Almaty. Moreover, the authors conducted a pilot online survey via Google forms, using convenient sampling via snowball technique $(\mathrm{N}=102)$, to collect data about commuting characteristics in the Almaty region. The response rate is $72 \%$. The survey consisted of 10 questions about gender, age, income, hours of travel, etc. In order to analyze the results of the survey descriptive statistics methods are used. The crosstabulations (using SPSS software) serve to show the relationship within the received data.

\section{Results}

Due to the urban development and population growth, the city's economy cannot keep up with the growing population. Accordingly, the city grows not only intensively, but also extensively, turning into an urban agglomeration and joining suburban settlements and small towns. However, the periphery of the agglomeration cannot fully satisfy the supply of the labor market. Therefore, people living in the suburbs are forced to travel to the city on a daily basis for the purpose of work, study, etc. This, in turn, affects the transport system, creating traffic congestions. A large amount of exhaust fumes from transport harms the ecological environment. Inconvenient transport systems, travel times, and additional problems during travel negatively affect the well-being of commuting migrants [2, p. 2779].

In order to understand commuting patterns, it is important to analyze their characteristics such as age, gender, income level. Firstly, the results of the pilot survey show that the preferably young population tends to commute (Figure 1, p. 142). 


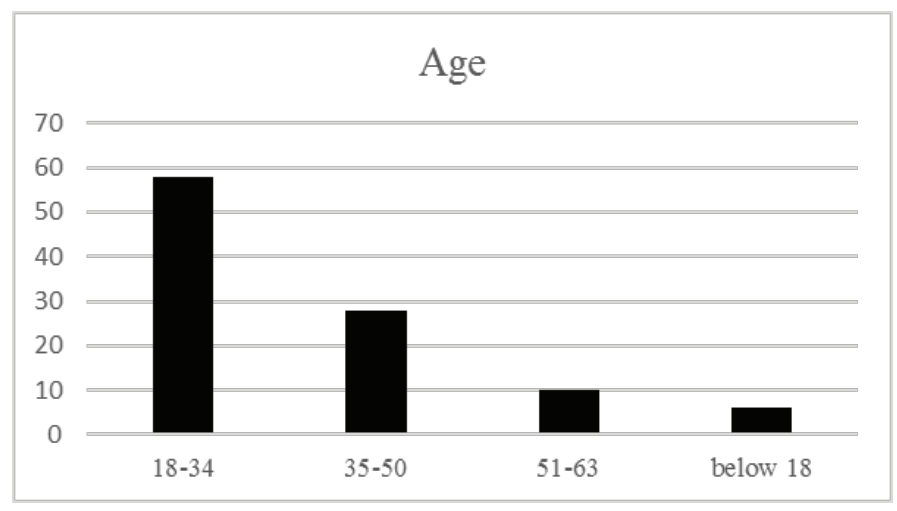

Figure 1 - Age share of respondents

Note - Source - Compile on the base of the survey results.

According to pilot survey results, it can be seen that the share of females is larger than the share of the male population (Figure 2).

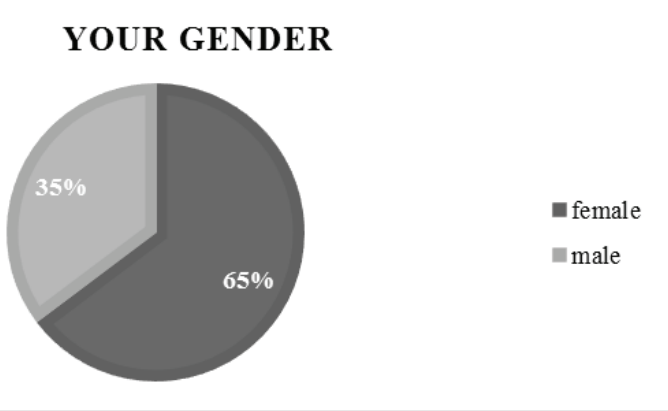

Figure 2 - The share of male and female population

Note - Source - Compiled on the base of the survey results.

Table 1 - Cross-tabulation analysis of the mode of transport and hours spent on travel

\begin{tabular}{|c|c|c|c|c|c|}
\hline \multicolumn{6}{|c|}{ Transport * hours crosstabulation } \\
\hline \multicolumn{6}{|l|}{ Count } \\
\hline & & & tours & & \multirow[b]{2}{*}{ Total } \\
\hline & & $\begin{array}{c}\text { less than } 2 \\
\text { hours }\end{array}$ & $\begin{array}{c}2-3 \\
\text { hours }\end{array}$ & 3-4 hours & \\
\hline \multirow{2}{*}{ transport } & public & 20 & 40 & 10 & 70 \\
\hline & private & 18 & 7 & 7 & 32 \\
\hline \multicolumn{2}{|l|}{ Total } & 38 & 47 & 17 & 102 \\
\hline
\end{tabular}

Table 2 - Correlation analysis of the mode of transport and hours spent on travel

\begin{tabular}{|c|c|c|c|c|c|}
\hline \multicolumn{6}{|c|}{ Symmetric Measures } \\
\hline & & Value & $\begin{array}{l}\text { Asymptotic } \\
\text { Standard Error }\end{array}$ & Approximate $\mathrm{T}^{\mathrm{b}}$ & $\begin{array}{l}\text { Approximate } \\
\text { Significance }\end{array}$ \\
\hline $\begin{array}{ll}\text { Interval } & \text { by } \\
\text { Interval } & \\
\end{array}$ & Pearson's R & $-0,132$ & 0,108 & $-1,334$ & $0,185^{\mathrm{c}}$ \\
\hline $\begin{array}{ll}\text { Ordinal } & \text { by } \\
\text { Ordinal } & \\
\end{array}$ & Spearman Correlation & $-0,160$ & 0,110 & $-1,620$ & $0,108^{c}$ \\
\hline \multicolumn{2}{|l|}{$\mathrm{N}$ of Valid Cases } & 102 & & & \\
\hline
\end{tabular}


Commuting patterns are adapting to developing municipal dispersion and may be self-modifying in a way that decreases traffic congestion and travel commute times and can considerably impact the concept of the threshold of commuting. However, due to the fact that the metropolitan system of Almaty city does not cover the entire agglomeration, people use private cars and buses as a mode of transport (Figure 4). This can impact the average commuting time. The results of the pilot survey show that most respondents spend 2-3 hours on travel to work (Figure 3). In comparison, the average oneway commute in the United States increased to a new high of 27.6 minutes in 2019, making up 55.2 minutes to a two-way commute [10].

Table 3 - Cross-tabulation analysis of the mode of transport and income of respondents

\begin{tabular}{|c|c|c|c|c|c|c|c|c|}
\hline \multicolumn{9}{|c|}{ transport * income Crosstabulation } \\
\hline \multicolumn{9}{|l|}{ Count } \\
\hline & & \multicolumn{6}{|c|}{ income } & \multirow[b]{2}{*}{ tota } \\
\hline & & $\begin{array}{l}100-200 \\
\text { thousand }\end{array}$ & $\begin{array}{r}200-300 \\
\text { thousand }\end{array}$ & $\begin{array}{c}300-400 \\
\text { thousand }\end{array}$ & $\begin{array}{c}\text { less than } 100 \\
\text { thousand }\end{array}$ & $\begin{array}{c}\text { more than } 400 \\
\text { thousand }\end{array}$ & unemployed & \\
\hline \multirow[t]{2}{*}{ transport } & private & 9 & 7 & 1 & 2 & 3 & 10 & 32 \\
\hline & public & 28 & 19 & 1 & 7 & 0 & 15 & 70 \\
\hline \multicolumn{2}{|l|}{ total } & 37 & 26 & 2 & 9 & 3 & 25 & 102 \\
\hline
\end{tabular}

The reason to commute can vary, it depends on a person's income level, labor market, and personal preferences. The reasons why respondents do not desire to move to the city are shown in Figure 3 .

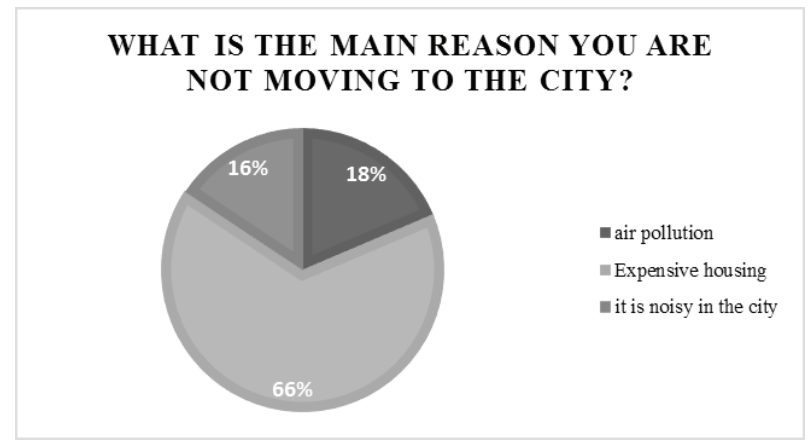

Figure 3 - The reasons for not moving of respondents

Note - Source - Compiled on the base of the survey results.

Air pollution in Almaty remains an important issue. Traffic within the city and from the periphery to the center of agglomeration has a huge impact on air pollution. The study on air quality changes in Almaty shows that during lockdown the PM2.5 concentration was reduced by $21 \%$ with spatial variations of 6-34\% compared to the average on the same days in 2018-2019 [11]. This occurred due to the regulation of mobility during a lockdown, since it was forbidden to enter from the region to the city, except in some urgent cases.

Commuting behavior has been found to have an impact on various dimensions of workers' daily lives. For instance, Ross and Zenou [12] all found a negative correlation between commuting and worker productivity, in terms of sickness absenteeism or shirking behaviors. Several authors such Gimenez-Nadal and Molina, Schafer et al. have also found negative links between commuting and worker health outcomes, including subjective wellbeing, psychological problems, increased stress, and subjective health. According to pilot survey results, respondents mostly struggle with traffic congestion (Figure 4). 


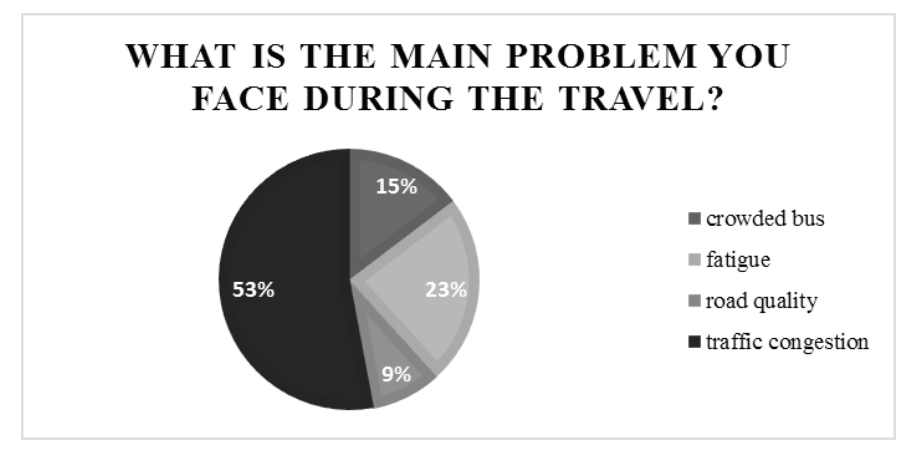

Figure 4 - Problems during the travel

Note: Source - Compiled on the base of the survey results.

\section{Discussion}

Another essential aspect of commuting is gender differences. Over the years the gender differences of commuting were studied by scholars worldwide. Most studies suggest that women tend to spend less time on the journey to work and travel shorter distances than men. The cross-tabulation between income level and gender of respondents is presented in Table 3 in the Appendix section.

Commuting, or more accurately the willingness to commute, demonstrates a significant factor in the employment and income level of individuals, as it directly impacts the geographical size of a person's labor market. The central urban sites can present diverse job opportunities with higher wages, however, longer commutes hence can present additional costs to commuters. Therefore, in order to compensate for these additional costs associated with commuting, commuters are more likely to accept job offers with appropriate wages [13].

Studying commuting is also important for traffic management and transport flow predictions. In the case of the Almaty region, urban road transport has become an integral part of the modern life of the population. According to Murzhakmetova et. al. [14] currently, there are problems with road traffic organization in the major cities of Kazakhstan, especially in their central parts. This can be explained by the increase in private car use, the low quality and malfunction of the roads.

\section{Conclusion}

Commuting plays a significant role in understanding urban and agglomeration development, as it affects people, the environment and the economy as a whole. According to Strategy 2050 of Kazakhstan, one of the pillars is a sustainable urbanization rate. Therefore, this process should be studied, especially in Kazakhstan, paying attention to the interdisciplinary approach. The results of pilot survey contribute to further research of commuting patterns in the Almaty region, especially studying the impact of expensive housing, air pollution and traffic congestion on commuting behavior.

\section{REFERENCES}

1 Haas A., Osland L. Commuting, Migration, Housing and Labour Markets: Complex Interactions. Urban Studies, 2014, no. 51(3), pp. 463-476. URL: https://doi.org/10.1177/0042098013498285 (Accessed 28 August 2021)

2 Clark B., Chatterjee K., MartinA., Davis, A. How commuting affects subjective wellbeing. Transportation, 2019, no. 47(6), pp. 2777-2805. URL: https://doi.org/10.1007/s11116-019-09983-9 (Accessed 2 September 2021)

3 Carlino G.A., Kerr W.R. Agglomeration and Innovation (Innovaatiot Ja Kasautuminen). SSRN Electronic Journal. 2015. URL: https://doi.org/10.2139/ssrn.2702694 (Accessed 2 September 2021)

4 Fang C., Yu D. Urban agglomeration: An evolving concept of an emerging phenomenon. Landscape and urban planning, 2017, no. 162, pp. 126-136. 
5 Seitz W. Urbanization in Kazakhstan: desirable cities, unaffordable housing, and the missing rental market. International Journal of Urban Sciences, 2020, no. 25(sup1), pp. 135-166. URL: https://doi.org/10.1 080/12265934.2019.1709534 (Accessed 2 September 2021)

6 Roback J. Wages, Rents and the Quality of Life. Journal of Political Economy, 1982, no. 90(6), pp. $1257-1278$.

7 Crane R. The Influence of Uncertain Job Location on Urban Form and the Journey to Work. Journal of Urban Economics, 1996, no. 39(3), pp. 342-356.

8 Ma K., Banister D. Excess Commuting: A Critical Review. Transport Reviews, 2006, no. 26(6), pp. $749-767$.

9 Glaeser E.L., Laibson D.I., Scheinkman J.A., Soutter C.L. Measuring Trust*. Quarterly Journal of Economics, 2000, no. 115(3), pp. 811-846. URL: https://doi.org/10.1162/003355300554926 (Accessed 5 September 2021)

10 Nine days on the road. Average commute time reached a new record last year. The Washington Post, 2019. URL: https://www.washingtonpost.com/business/2019/10/07/nine-days-road-average-commute-timereached-new-record-last-year/

11 Assanov D., Zapasnyi V., Kerimray A. Air Quality and Industrial Emissions in the Cities of Kazakhstan. Atmosphere, 2021, no. 12(3), p. 314. URL: https://doi.org/10.3390/atmos12030314 (Accessed 7 September 2021)

12 Ross S.L., Zenou Y. Are shirking and leisure substitutable? An empirical test of efficiency wages based on urban economics theory. Regional Science and Urban Economics, 2008, no. 38, pp. 498-517.

13 Zabel J.E. Migration, housing market, and labor market responses to employment shocks. Journal of Urban Economics, 2012, no. 72(2-3), pp. 267-284. URL: $\quad$ https://doi.org/10.1016/j.jue.2012.05.006 (Accessed 11 September 2021)

14 Murzakhmetova U.A., Sabraliev N.S., Alshynova A.M., Tundybaeva E.T. Problems of urban traffic organizations in a large city of the republic of Kazakhstan (on the example of Almaty). The Journal of Almaty Technological University, 2021, pp. 94-100

К.Т. КАБДЕСОВ, $* 1$

магистр, аға оқытушы.

*e-mail: kabdesov.k@uib.kz

А.В. МАЛДЫНОВА, ${ }^{1}$

магистр, аға оқытушы.

e-mail: maldynova.a@uib.kz

${ }^{1}$ Кенжеғали Сағадиев атындағы

Халықаралық бизнес университеті

Қазақстан, Алматы қ.

\title{
АЛМАТЫ АГЛОМЕРАЦИЯСЫНДАҒЫ ҚАТЫНАМАЛЫ КӨШІҚОН: ПИЛОТТЫҚ САУАЛНАМА НӘТИЖЕЛЕРІН ТАЛДАУ
}

\begin{abstract}
Андатпа
Қатынамалы көші-қон - бұл, әдетте, ірі қалалар мен агломерацияларда күнделікті орын алатын процесс. Шеткері жерлерде тұратын адамдар агломерация орталығындағы жұмыс орындарына дейін сапар жасайды. Қатынамалы көші-қон халық арасында әр түрлі болуы мүмкін және бұл адамдардың экономикалық және қаржылық жағдайы, еңбек нарығы және т. б. сияқты ішкі және сыртқы факторларға байланысты. Күнделікті белсенділік қатынамалы көші-қонның орталық тұжырымдамасы болса да, ол әртүрлі нысандарда жүзеге асырылады және әртүрлі әлеуметтік-демографиялық, экономикалық және кеңістіктік факторларға байланысты. Демек, қатынамалы көші-қонмен байланысты тенденциялардағы, модельдердегі және мінез-құлықтағы әлеуметтік-демографиялық және экономикалық айырмашылықтар зерттеу нысаны болып табылады. Алматы қаласы - Қазақстанның халық тығыз орналасқан аумақтарының бірі. Урбанизация және қала құрылысы процестерінің арқасында қала жаңа аумақтарды басып алып, агломерацияға айналады. Бұл адамның күнделікті ұтқырлығының артуына әкеледі. Агломерацияның шетінде тұратын, бірақ қала орталығында жұмыс істейтін адамдар күнделікті сапарлар жасайды. Қатынамалы көші-қонды зерттеу қаланың дамуы үшін маңызды. Осы мақаланың мақсаты - Алматы облысында жүргізілген пилоттық сауалнама нәтижелерін талдау негізінде қатынамалы көші-қон сипаттамаларын анықтау болып табылады. Сауалнама нәтижелерін талдау үшін сипаттамалық статистика әдістері қолданылады.
\end{abstract}

Тірек сөздер: қатынамалы көші-қон, урбандалу, агломерация, субурбанизация, қала экономикасы, сауалнама, санақ. 


\title{
К.Т. КАБДЕСОВ, ${ }^{1 *}$ \\ магистр, ст. преподаватель. \\ *e-mail: kabdesov.k@uib.kz \\ А.В. МАЛДЫНОВА, ${ }^{1}$ \\ магистр, ст. преподаватель. \\ e-mail: maldynova.a@uib.kz \\ ${ }^{1}$ Университет международного бизнеса \\ имени Кенжегали Сагадиева, \\ Казахстан, г. Алматы
}

\section{МАЯТНИКОВАЯ МИГРАЦИЯ В АЛМАТИНСКОЙ АГЛОМЕРАЦИИ: АНАЛИЗ РЕЗУЛЬТАТОВ ПИЛОТНОГО ОПРОСА}

\begin{abstract}
Аннотация
Маятниковая миграция - это процесс, протекающий на ежедневной основе, как правило, в крупных городах и агломерациях. Люди, живущие на периферии, совершают поездку до места работы в центр агломерации. Маятниковая миграция может варьироваться среди населения, и это объясняется внутренними и внешними факторами, такими как экономическое и финансовое положение людей, рынок труда и т.д. Несмотря на то что рутинная деятельность является центральной концепцией маятниковой миграции, она осуществляется в разных формах и зависит от различных социально-демографических, экономических и пространственных факторов. Следовательно, именно эти социально-демографические и экономические различия в тенденциях, моделях и поведении, связанных с маятниковой миграцией, являются объектом исследования. Город Алматы - один из самых густонаселенных территорий Казахстана. Благодаря процессам урбанизации и градостроительству город захватывает новые территории и становится агломерацией. Это приводит к увеличению повседневной мобильности людей. Люди, живущие на периферии агломерации, но работающие в центре города, совершают ежедневные поездки. Изучение маятниковой миграции важно для развития города. Целью данной статьи является выявление характеристик маятниковой миграции на основе анализа результатов пилотного опроса, проведенного в Алматинской области. Для анализа результатов опроса используются методы описательной статистики.
\end{abstract}

Ключевые слова: маятниковая миграция, урбанизация, агломерация, субурбанизация, городская экономика, опрос, статистика. 